Egyptian Journal of Aquatic Biology \& Fisheries

Zoology Department, Faculty of Science,

Ain Shams University, Cairo, Egypt.

ISSN $1110-6131$

Vol. 25(2): $487-508$ (2021)

www.ejabf.journals.ekb.eg

\title{
Comparison between the toxicity of Copper and Irgarol 1051 as two different generations of antifoulings on growth and essential metabolites of marine algae (Dunaliella salina as a case study)
}

\author{
Mona Kaamoush $^{* 1}$ and Nagwa El- Agwany ${ }^{2}$
}

1-Environmental and Crises Management Department, simulator complex, Arab Academy for Science, Technology and Maritime Transport, Egypt.

2- Botany and Microbiology Department, Faculty of Science Alexandria University, Egypt.

*Correspondance Author: monaabdelnaby777@yahoo.com

\begin{abstract}
ARTICLE INFO
Article History:

Online: April 18, 2021

Keywords:

Copper;

Irgarol 1051;

Dunaliella salina;

protein;

carbohydrates;

antifoulings.
\end{abstract}

Received: Nov. 12, 2020

Accepted: March 30, 2021

\section{ABSTRACT}

The present study aims to compare the toxicity effect of Copper and Irgarol 1051 as antifouling agents on metabolites products in marine algae Dunaliella salina. Different concentrations of $\mathrm{Cu}(5,15 \& 25 \mathrm{mg} / \mathrm{l})$ and Irgarol $1051(0.012,0.025 \& 0.050 \mu \mathrm{g} / \mathrm{l})$ were laboratories prepared and their impacts on growth, protein, and carbohydrates in Dunaliella salina were tested. Selections of these concentrations were initiated based on the response of the studied alga which had slightly or marked effects on its growth, and also to avoid the non-effective and directly lethal concentrations on the experimented alga. The obtained results showed stimulation in the growth of algae under the effect of the lowest concentration of the two tested antifoulings, however, there was a suppression of algal growth by increasing the concentration of the two antifoulings but with different degrees. There was a clear inhibition of protein and carbohydrate production by increasing the concentration of the two tested antifoulings. Also, Irgarol 1051 showed a toxic effect higher than Copper, which is one of the essential micronutrients in the marine ecosystem.

\footnotetext{
INTRODUCTION

The term biofouling is commonly employed to distinguish the undesirable accumulation of microorganisms such as bacteria, fungi and microalgae, plants and invertebrates on any artificial surfaces submerged in seawater (Yebra $\boldsymbol{e t}$ al., 2004) from those occurring on rocks and other natural objects. The organism occurring in fouling have been recorded frequently, nearly 2000 species of animals and plants have been reported from fouling. This included 615 kinds of plants and 1361 varieties of animals. Although the number of species reported from fouling is large and is widely distributed among the existing groups of organisms, it actually includes a very small proportion of the known marine species. However, adsorption and accumulation of marine organic (e.g. algae, worms and
} 
mollusks) to marine equipment (e.g. vessel, pontoons, piers and pipelines) can aggravate wear and lead to lower running speed, higher energy consumption and poorer operability, which may pose a great danger of sailing (Almeida, 2007). In addition, these marine infrastructures that are submerged in seawater are much easier suffered from corrosion. Corrosion and fouling become the major problems to work out. Besides, anti-fouling materials and anti-corrosion materials have been widely researched and used (Xuebing $\boldsymbol{e t}$ al., 2018).

In antifouling marine paints typically up to $40 \%$ (wt.), $\mathrm{Cu}$ (largely in the form of $\mathrm{Cu}$ (I) oxide) is being used. Excessive $\mathrm{Cu}$ concentrations observed along the coastal and harbor areas of different parts of the world are mainly due to $\mathrm{Cu}$ based AF paints (Valkirs et al., 2003). Especially, in enclosed marinas and harbors where tidal influence is less, the $\mathrm{Cu}$ levels are expected to be very high. This may lead to elimination of susceptible microalgal species causing phenomenal changes like incidence of monospecific fouling communities (Chi et al., 2006).

Today, most antifouling paints are based on copper compounds, e.g. cuprous oxide (Amara et al., 2018). Copper is an essential element for all living organisms and play important roles in many metabolic processes (Ochoa-Herrera et al., 2011). However, copper may also be toxic to most species when concentrations exceed levels that are physiologically required (Strivens et al., 2020).

Copper is found naturally in the marine environment and is an essential element in the enzyme activity necessary for healthy metabolic functioning as well as the growth and metamorphosis of many organisms (Lewis and Cave, 1982). Copper becomes toxic when, in a bioavailable form, it exceeds the threshold of the organism's tolerance, and this has been shown to vary widely between life stages (Xie et al., 2005) and even between species within the same taxonomical group (Han et al., 2008). Copper toxicity is also strongly influenced by environmental factors that govern copper speciation and hence its bioavailability (Srinivasan and Swain, 2007).

Natural background concentrations of copper in seawater are estimated between 0.5 and 3 $\mu \mathrm{g} / \mathrm{l}$, but concentrations up to $21 \mu \mathrm{g} / \mathrm{l} \mathrm{Cu}$ have been found in contaminated areas. A recent risk assessment on the use of copper as a biocide in antifouling paints considered the concentration, speciation and effects of copper in the coastal marine environment, and inputs from AF paints. Copper toxicity was a potential problem in isolated water bodies, such as enclosed marinas and harbours with little water exchange and high levels of boating activity and recommended ongoing development of improved and environmentally friendly AF products that would reduce copper usage (Brooks and Waldock, 2009).

Irgarol 1051 (2-methylthio -4-terbulylamino -6- cyclopropylamino -s-triazine) is used in aquatic antifouling paints after the restriction of using tributyltin (TBT) as antifouling agent (Zamora-Ley et al., 2006). Irgarol may affect non-target photosynthetic organisms 
such as phytoplankton, periphyton and aquatic macrophytes when leaching into the marine environment (Dahl and Blanck, 1996; Hall et al., 1999).

The active ingredients in the paints biocides (mainly copper and organostanous compounds) leach from the coating of ships and thereby contaminate the aquatic environment (Konstantinou and Albanis, 2004). Thus, in areas with high boating activities many of these leached substances (biocides) occur as mixtures. Occurrence of Irgarol 1051 has been widely reported in coastal waters of many countries; Red Sea, Mediterranean Sea, Japan, Australia, Europe, United States and many others (Biselli $\boldsymbol{e} t$ al., 2000; Key et al., 2008).

Increasing concentration of Irgarol in coated waters up to 0.048 to $0.068 \mu \mathrm{g} / \mathrm{l}$ have been reported by Bascher et al. (2002). Concentrations of Irgarol 1051 have been found to be highest and adjacent to marines and fishing harbours range between 0.02 and $0.70 \mu \mathrm{g} / \mathrm{l}$, the toxic effects of Irgarol 1051 against algae, crustaceous and fish have been reported by Van Wezel and Van Vlaardingen (2004).

Readmann et al. (2004) reported toxic effects of Irgarol 1051 at low concentrations of $0.07 \mu \mathrm{g} / \mathrm{l}$. Irgarol 1051 was firstly reported as an aquatic contaminant in the Mediterranean since 1993 (Readmann et al., 1993). Knowledge about the fate of these toxic chemicals in aquatic environments (fresh or marine) is essential for understanding and predicting the possibility of ecotoxic ecology effects.

In this research, Dunaliella salina was selected for the study due to different important reasons. Species of the genus Dunaliella have been the subject of extensive research on their physiology, biochemistry, ecology, molecular biology, and for commercial applications. Dunaliella species occur in hypersaline to brackish water habitats from the tropics to Antarctica. The microalga Dunaliella salina is the best commercial source of natural $\beta$ - carotene and can accumulate significant amounts of valuable fine chemicals such as carotenoids, glycerol, lipids, vitamins, minerals, carbohydrates and proteins. Also, different species of Dunaliella have a large potential for biotechnological processes such as expressing of foreign proteins and treatment of wastewater (Hosseini, 2009). Microalgae such as Dunaliella salina, Haematococcus pluvialis and Spirulina sp. are also used as a source of natural pigments for the culture of prawns, salmonid fish and ornamental fish. Dunaliella sp., Chlorella sp. and Spirulina sp. are three major types that have been used successfully to produced high concentrations of valuable compounds such as lipids, protein, carbohydrates and pigments. Present study aims to compare toxicity effect of Copper and Irgarol 1051 as antifouling on growth and the production of essential metabolites (protein and carbohydrates) in marine algae Dunaliella salina.

\section{MATERIALS AND METHODS}

\section{A- Biological material}

The selective biological material is the unicellular microalga Dunaliella salina usually used for fish feeding; obtained from the culture collection of Botany department, Faculty 
of Science, Alexandria University. The axenic cultures of Dunaliella salina was grown on MH medium (Loeblich, 1982). The cells of 8-10 days old cultures were harvested by centrifugation at 10.000 r.p.m. for 20 min using angle rotor centrifuge. The supernatants were discarded and the remaining pellets were used for the determination of growth, protein and carbohydrates. The growth of the investigated alga was determined by cell count using the hemacytometer slide. The growth was calculated by using the formula proposed by Stein (1973).

\section{B- Heavy metal bioassay:}

Stock solutions of the selected heavy metal were prepared from its salt in double distilled water and sterilized by filtration through $0.2 \mu \mathrm{m}$ nitrocellulose membranes. According to Wong and Pak (1992), a preliminary experiment using a wide range of metal solutions $\left[\mathrm{CuSO}_{4} \cdot 5 \mathrm{H}_{2} \mathrm{O}\right]$ was carried out to determine the suitable concentrations of the metal salts which could be tolerated by the studied alga. Selections of these concentrations were based on the response of the studied alga which had a slightly or marked effects on its growth, and also to avoid the non-effective and directly lethal concentrations on the experimented alga.

\section{C- Preparation of Irgarol:}

The herbicide triazine (Irgarol 1051) was purchased from Fluka Company. The stock solution $1000 \mathrm{mg}$ of the standard Irgarol 1051 was prepared in acetone and stored in dark at $4^{\circ} \mathrm{C} .0 .1 \mathrm{ml}$ of stock solution was mixed with $100 \mathrm{ml}$ of sterilized distilled water. The mixtures were stirred by a magnetic stirrer for half an hour. Dilution of this stock solution was done by the selected culture medium for preparing the different concentrations of Irgarol. These concentrations were selected after several experiments to select the suitable concentrations. These concentrations were nearly within the range of those found in marines.

\section{D- Determination of total protein and its fractions:}

In this investigation protein was determined by the method described by Hartree (1972) which is the modification of the original folin-phenol method of Lowery et al., (1951). The method depends on reaction of protein with copper in alkali, then reduction of the phosphomolybdic reagent by the copper treated protein. The protein content was calculated from a standard curve made from working standards of similarly treated bovin serum albumen as $\mathrm{mg} / \mathrm{L}$ culture.

\section{*Preparation of algal extract for protein analysis:}

Protein was extracted from the algal cells according to the method described by Rauch, (1981) in a test tube $3-\mathrm{ml}$ of $0.5 \mathrm{~N} \mathrm{NaOH}$ were added to the cell pellets obtained by centrifugation from 5-ml culture, shaked well and extracted at $80^{\circ} \mathrm{C}$ in a water bath for 10 minutes with occasionally stirring. The extract was quickly cooled at room temperature (using running cold water), centrifuged at $5000 \mathrm{rpm}$ for 20 minutes and the supernatant was transferred to a graduated cylinder $(10 \mathrm{ml})$. 
Extraction was repeated two times with $0.5 \mathrm{~N} \mathrm{NaOH}$ for $10 \mathrm{~min}$ at $80^{\circ} \mathrm{C}$. The combined supernatants were completed to a definite volume $(10 \mathrm{ml})$ mixed well and used for protein measurement.

\section{*Total Protein estimation:}

\section{Reagents:}

- Reagent A: two gm potassium sodium tartarate and $100 \mathrm{~g}$ sodium carbonate dissolved in 1 liter of $0.5 \mathrm{~N} \mathrm{NaOH}(0.9 \mathrm{ml}$ used for each determination).

- Reagent B: two gm potassium sodium tartarate and $1.0 \mathrm{~g} \mathrm{CuSO}_{4} .5 \mathrm{H}_{2} \mathrm{O}$ dissolved in $100 \mathrm{ml} 0.1 \mathrm{~N} \mathrm{NaOH}(0.1 \mathrm{ml}$ was used each determination).

- Reagent C: one volume Folin ciocalteu reagent diluted ten fold with distilled water (3.0 $\mathrm{ml}$ were used for each determination)

\section{Procedure:}

Reagent A was added first to one ml centrifuged clear extract and to the blank or standard solution in a test tube and heated in water bath at $50^{\circ} \mathrm{C}$ for $10 \mathrm{~min}$. cooled rapidly in ice. Reagent B was then added and the tube was left for at least $10 \mathrm{~min}$ at room temperature. Reagent $\mathrm{C}$ was then added and mixed well by whiler mixer, placed in water bath at $50^{\circ} \mathrm{C}$ for $10 \mathrm{~min}$., then cooled rapidly. The intensity of the blue colour developed in each sample was measured using a spectrophotometer (Berkin -Elmer) at $650 \mathrm{~nm}$ and readings were then related to the standard curve.

\section{*Determination of water soluble proteins:}

Aliquots (10 mls) of algal suspension were centrifuged. The algal precipitate was boiled in $10 \mathrm{mls}$ distilled water for two hours. After cooling, the water extract was centrifuged and the supernatant was decanted and completed to a definite volume by distilled water and analyzed for determination of soluble proteins according to the method of total protein content.

\section{* Determination of water-insoluble proteins:}

It was calculated as the difference between the total and water-soluble protein fractions of the same sample.

\section{E- Measurements of carbohydrates content:}

Carbohydrates content were estimated according to the method described by Dubois $\boldsymbol{e t}$ al., (1959).

\section{*Determination of total carbohydrates:}

In a test tube two mls of $\mathrm{N} \mathrm{HCl}$ were added to the-cell pellets -obtained from $5 \mathrm{ml}$ culture after centrifugation and shaken well for complete homogeneity. The mixture was transferred to a clean test tube and then boiled for $20 \mathrm{~min}$. (a time was found to be enough for complete hydrolysis) in a boiling water bath for complete hydrolysis. After cooling at room temperature, the extract is clarified by centrifugation for five minutes at $2000 \mathrm{rpm}$. In a clean test tube $0.5 \mathrm{ml}$ of the clear supernatant and $0.5 \mathrm{ml}$ of $5 \%$ phenol solution was added and mixed well. To each tube $2.5 \mathrm{ml}$ of $98 \% \mathrm{H}_{2} \mathrm{SO}_{4}$ were added rapidly so that the stream hit the liquid surface directly to produce good mixing. Tubes were equally 
agitated during the acid addition. Blank was also treated in the same manner, but $0.5 \mathrm{ml}$ distilled water was used instead of algal extract. After ten minutes, the tube were reshaken and placed in a water bath at $25-30^{\circ} \mathrm{C}$ for $20 \mathrm{~min}$. The developed yellow-orange color was stable for several hours. The optical density was determined at $488 \mathrm{~nm}$ and compared to calibration standard curve.

\section{*Determination of water- soluble carbohydrates:}

To estimate water-soluble carbohydrates, $5 \mathrm{ml}$ culture from each algal culture was centrifuged and the supernatant was decanted. After decantation, the algal precipitate was extracted by distilled water for two hours in a boiling water bath. After cooling, the soluble fraction was separated by centrifugation and completed to a definite volume. Then the water soluble carbohydrates were determined by the method mentioned previously in case of total carbohydrates.

\section{*Determination of water-insoluble carbohydrates content:}

It was calculated as the difference between the total carbohydrates and the water soluble carbohydrates of the same sample.

\section{F- Statistical analysis:}

The obtained data were analyzed statistically using two ways ANOVA (Analysis of variance). The difference between means probability levels were analyzed using Duncan's New Multiple Range Test $(\mathrm{P}<0.05)$. F- test were also analyzed (LSD) the least significant difference at 0.05 .

\section{RESULTS AND DISCUSSION}

\section{1-Growth}

$\mathrm{Cu}$ is having an essential role in the algal metabolism (Thompson et al., 1987; Lage et al., 1996). However, in higher concentrations $\mathrm{Cu}$ tends to damage the cell wall membrane function, Chi et al., (2006). Copper is also universally used as biocide as it is lethal to microorganism at higher concentrations (Rhie and Lee, 1999). Copper concentrations less than $1 \mu \mathrm{g} / \mathrm{l}$ retard the growth of fresh and marine microalgal species (Davey et al., 1973). Coatings containing increasing cuprous oxide concentrations that were exposed in a pleasure craft marina in Gothenburg, i.e. in the region Baltic Transition (Lindgren et al., 2018). All investigated copper coatings were efficient in preventing macrofouling and copper was determined to be $\leq 4.7 \mu \mathrm{g} / \mathrm{cm} 2 / \mathrm{d}$, indicating that coatings with even lower release rates of copper may be sufficient in preventing macrofouling.

It is clear from the results recorded in Table (1) and Figures (1-A\&B) that maximum growth value of Dunaliella salina was reached at the $8^{\text {th }}$ day of culturing. This is coincident with the results obtained by Ben-Amotz and Avon (1981), El-Maghrabi, (1997) and Sahar, (1998). Low concentration of $\mathrm{Cu}^{2+}$ ions $(5 \mathrm{mg} / \mathrm{l})$ stimulates the growth of this organism compared to control. Further with the increase in concentration of $\mathrm{Cu}^{2+}$ ions $(15,25 \mathrm{mg} / \mathrm{l})$, the cell number decreased gradually till the end of the experiment 
compared to concentration $5 \mathrm{mg} / \mathrm{l}$. Event at the last two days of culturing (12-14 day) the organism disappeared completely at concentration $25 \mathrm{mg} / \mathrm{l}$.

Anent the effect of different concentration of Irgarol $1051 \mathrm{viz} 0.012,0.025$ and $0.050 \mu \mathrm{g}$ / 1 on the growth of Dunaliella salina cultured for 14 days revealed that, gradual increase in number of cells till the end of the experiment in case of concentration $0.012 \mu \mathrm{g} / \mathrm{l}$, percontra at concentrations 0.025 and $0.050 \mu \mathrm{g} / 1$ was great decrease in number of cells after $6^{\text {th }}$ day till the end of the experiment compared to concentration $0.012 \mu \mathrm{g} / \mathrm{l}$. There was suppression of algal growth under the effect of the different tested concentrations of Irgarol may be due to the increasing of toxicity of this biocide. The same results were also obtained by Munnas (2003); Singla and Garg (2005). Our results would contradict the study of Gatidou et al. (2003) who suggested that Irgarol had a lethal effect on Dunaliella tertiolecta and it inhibits growth at concentration higher than $0.8 \mu \mathrm{g} / 1$ and at concentration $3.0 \mu \mathrm{g} / \mathrm{l}$, the compound killed almost all the cells, also he found that, Dunaliella tertiolecta showed a 50\% decrease in growth rate during a $96 \mathrm{~h}$ exposure to about $3.95 \mathrm{nM}$ of Irgarol while at $11.84 \mathrm{nM}$ almost all cells were killed (96\% inhibition). The lethal effect of Irgarol was furthermore described in the ACE (2002) final report in which flow cytometric analyses revealed that approximately half of the phytoplankton was killed at concentrations as low as $0.39 \mathrm{nM}\left(100 \mathrm{ng} / \mathrm{l}^{-1}\right)$ (Anita et al., 2009).

Tsang et al. (1999) revealed that, sensitivity and response of microalgae to booster biocides varies from species to species, size of the cell wall composition, consequently some species appeared to be resistant to booster biocides and posses the ability to accumulate and/or degrade these compounds.

\section{2- PROTEIN}

A glance of result recorded in Table (2-A) and graphed in Figure (2-A), concerning the effect of different concentrations of $\mathrm{Cu}^{2+}$ and Irgarol 1051 on the protein fraction content (soluble, insoluble and total) in Dunaliella salina cultured for 16 days. Concentration of 5 $\mathrm{mg} / \mathrm{l} \mathrm{Cu}{ }^{2+}$ caused stimulatory effect of increasing protein content till the $8^{\text {th }}$ day of culturing then decreasing in the protein content soluble, insoluble and total) noticed till the end of the experiment. On the contrary at concentrations 15 and $25 \mathrm{mg} / \mathrm{lof} \mathrm{Cu}^{2+}$ a noticeable decrease in the content of soluble, insoluble and total protein could be observed from the first 4 days till the end of the experiment. At concentration $25 \mathrm{mg} / \mathrm{l}$ of $\mathrm{Cu}^{2+}$, there was a sharp decrease in protein content (soluble, insoluble and total) higher than in case of concentration $15 \mathrm{mg} / \mathrm{l}$ of $\mathrm{Cu}^{2+}$, and after the $12^{\text {th }}$ day there was no protein detected, that's mean concentration $25 \mathrm{mg} / \mathrm{l}$ of $\mathrm{Cu}^{2+}$ was highly toxic to this type of alga. Similar observations were also reported by El-Agawany, (2008) in case of Dunaliella tertiolecta. The importance of $\mathrm{Cu}^{2+}$ as an essential micro-nutrient and its effect in limiting algal growth was reported by many authors (Steeman-Nielsen and Wium-Anderson 1970; Wong and Chang, 1991 and Abdel-Hamid et al., 1992; Vymazal, 1995). Also, Stauber and Florence (1985a) reported that copper at concentrations higher than $5 \mathrm{mg} / \mathrm{l}$ 
inhibited the growth of $N$. closterium by $50 \%$ below control. Moreover, the toxic effect of copper on the growth of the marine alga Dunaliella tertiolecta was clearly demonstrated in the cultures treated with 10 and $12 \mathrm{mg} / \mathrm{l}$ copper as recorded by Abalade et al., (1995b).

Table (1): Number of cells $\mathrm{X} 10^{6}$ of Dunaliella salina cultured for 14 days at different concentrations of $\mathrm{Cu}^{2+}$ ions (mg/l) and at different concentrations of Irgarol $1051(\mu \mathrm{g} / \mathrm{l})$.

\begin{tabular}{|c|c|c|c|c|c|c|c|c|c|}
\hline \multirow{2}{*}{$\begin{array}{c}\text { Time } \\
\text { (Days) }\end{array}$} & \multirow[t]{2}{*}{ Conrrol } & \multicolumn{3}{|c|}{$\mathrm{Cu}$ concentrations $(\mathrm{mg} / \mathrm{l})$} & \multicolumn{3}{|c|}{ Irgarol concentrations $(\mu \mathrm{g} / \mathrm{l})$} & \multirow[t]{2}{*}{$\mathbf{F}(\mathbf{p})$} & \multirow[t]{2}{*}{ LSD } \\
\hline & & 5 & 15 & 25 & 0.012 & 0.025 & $\mathbf{0 . 0 5 0}$ & & \\
\hline $\mathbf{0}$ & $0.46 \pm 0.002^{\mathrm{a}}$ & $0.46 \pm 0.002^{\mathrm{a}}$ & $0.46 \pm 0.002^{\mathrm{a}}$ & $0.46 \pm 0.002^{\mathrm{a}}$ & $0.46 \pm 0.002^{\mathrm{a}}$ & $0.46 \pm 0.002^{\mathrm{a}}$ & $0.46 \pm 0.002^{\mathrm{a}}$ & $\begin{array}{c}0.000 \\
(1.000)\end{array}$ & 0.003 \\
\hline 2 & $0.53 \pm 0.002^{\mathrm{a}}$ & $0.53 \pm 0.003^{\mathrm{a}}$ & $0.53 \pm 0.003^{\mathrm{a}}$ & $0.52 \pm 0.003^{\mathrm{c}}$ & $0.53 \pm 0.001^{\mathrm{a}}$ & $0.53 \pm 0.003^{\mathrm{a}}$ & $0.46 \pm 0.004^{\mathrm{c}}$ & $\begin{array}{l}37.059^{*} \\
(<0.001)\end{array}$ & 0.003 \\
\hline 4 & $0.74 \pm 0.007^{\mathrm{a}}$ & $0.78 \pm 0.001^{b}$ & $0.66 \pm 0.003^{\mathrm{c}}$ & $0.64 \pm 0.001^{\mathrm{a}}$ & $0.67 \pm 0.02^{\mathrm{a}}$ & $0.53 \pm 0.01^{b}$ & $0.51 \pm 0.013^{\mathrm{c}}$ & $\begin{array}{c}812.857 * * \\
(<0.001)\end{array}$ & 0.004 \\
\hline 6 & $1.23 \pm 0.03^{\mathrm{a}}$ & $1.30 \pm 0.003^{b}$ & $1.18 \pm 0.002^{\mathrm{c}}$ & $0.91 \pm 0.003^{f}$ & $1.00 \pm 0.004^{b}$ & $0.64 \pm 0.004^{b}$ & $0.57 \pm 0.005^{\mathrm{c}}$ & $\begin{array}{c}15207.000 * * \\
(<0.001)\end{array}$ & 0.003 \\
\hline 8 & $2.23 \pm 0.02^{\mathrm{a}}$ & $2.84 \pm 0.002^{b}$ & $1.54 \pm 0.004^{\mathrm{a}}$ & $0.75 \pm 0.004^{\mathrm{e}}$ & $2.05 \pm 0.006^{b}$ & $0.70 \pm 0.008^{b}$ & $0.87 \pm 0.008^{\mathrm{c}}$ & $\begin{array}{c}31197.000 * * \\
(<0.001)\end{array}$ & 0.005 \\
\hline 10 & $2.93 \pm 0.002^{\mathrm{a}}$ & $3.14 \pm 0.001^{b}$ & $2.55 \pm 0.002^{\mathrm{c}}$ & $0.63 \pm 0.054^{\mathrm{e}}$ & $2.11 \pm 0.004^{b}$ & $0.70 \pm 0.04^{b}$ & $0.67 \pm 0.013^{\mathrm{d}}$ & $\begin{array}{c}57015.000 * * \\
(<0.001)\end{array}$ & 0.004 \\
\hline 12 & $3.33 \pm 0.02^{\mathrm{a}}$ & $3.35 \pm 0.003^{b}$ & $2.74 \pm 0.001^{\mathrm{d}}$ & $0.35 \pm 0.001^{f}$ & $2.45 \pm 0.007^{b}$ & $0.79 \pm 0.015^{\mathrm{c}}$ & $0.71 \pm 0.019^{\mathrm{c}}$ & $\begin{array}{c}225033.191 * * \\
(<0.001)\end{array}$ & 0.004 \\
\hline 14 & $2.58 \pm 0.04^{\mathrm{a}}$ & $2.49 \pm 0.003^{\mathrm{b}}$ & $0.92 \pm 0.004^{d}$ & --- & $1.63 \pm 0.01^{b}$ & $0.75 \pm 0.005^{\mathrm{c}}$ & $0.07 \pm 0.011^{\mathrm{d}}$ & $\begin{array}{c}370898.571 * * \\
(<0.001)\end{array}$ & 0.004 \\
\hline
\end{tabular}

F (p): F-test (ANOVA) and its significance between groups.

* : Statistically significant at $\mathrm{p} \leq 0.05$.

Different subscribts are significant .
LSD: Least significant difference at 0.05 .

**: Statistically significant at $\mathrm{p} \leq 0.01$

Data are expressed in mean $\pm \mathrm{SD}$

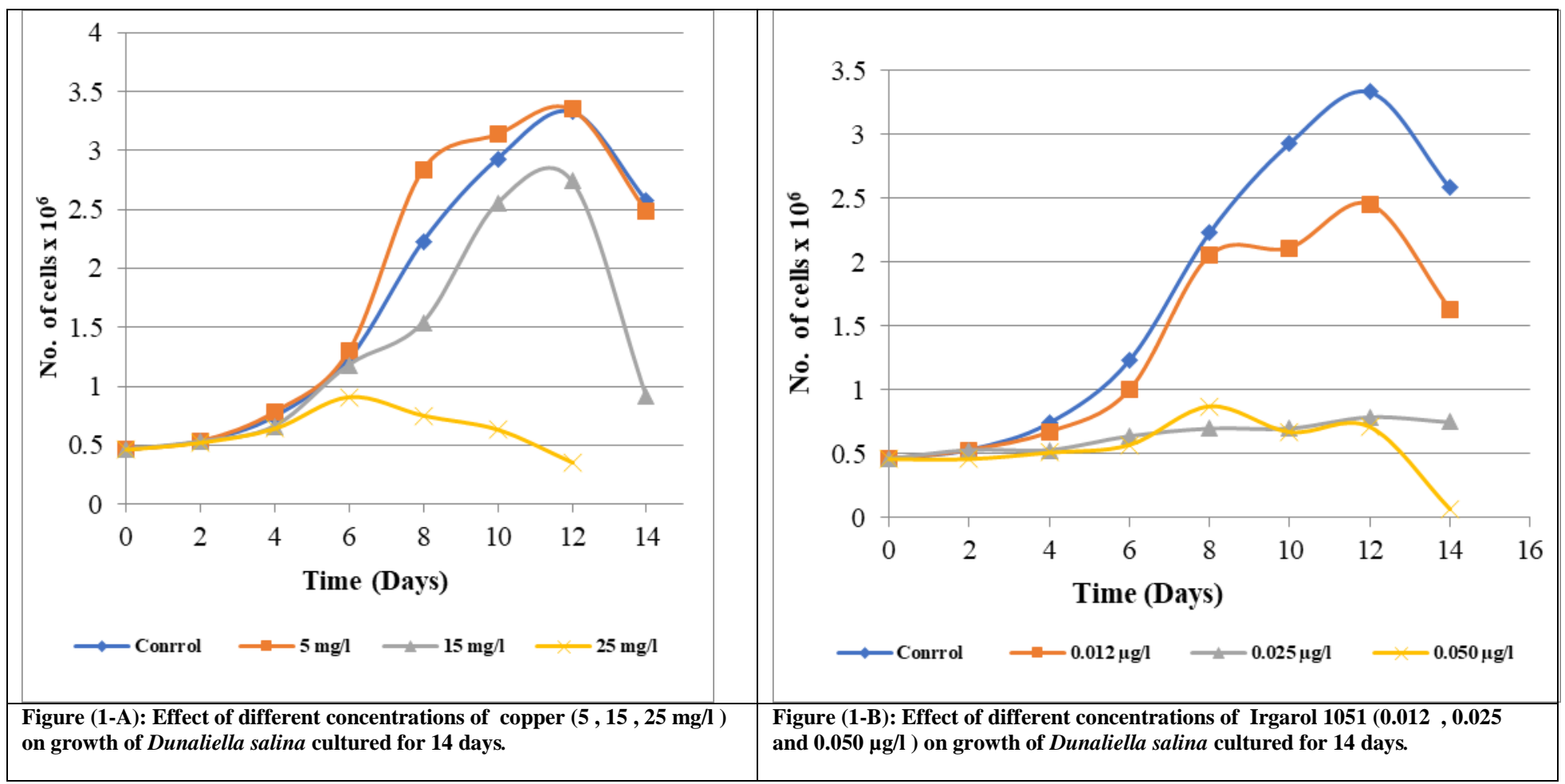


Owing to these data recorded in Table (2-B) and graphed in Figure (2-B) concerning the effect of different concentration of the antifouling Irgarol 1051 on the content of protein fractions of Dunaliella salina, it is clear that, the content of total proteins at the untreated cultures (control), and at concentration $0.012 \mu \mathrm{g} / \mathrm{l}$ Irgarol 1051 increased gradually till the end of the experiment. However, the rate of increase in case of concentration $0.012 \mu \mathrm{g} / \mathrm{l}$ Irgarol 1051 was less than in case of control. In case of the other two concentrations $(0.025 \& 0.050 \mu \mathrm{g} / \mathrm{l})$, total protein content reached its maximum value at the $8^{\text {th }}$ day of culturing but it was higher in case of concentration $0.025 \mu \mathrm{g} / \mathrm{l}$ than concentration 0.050 $\mu \mathrm{g} / \mathrm{l}(34.501 \& 26.470 \mathrm{mg} / \mathrm{ml}$ respectively).

The decrease in the content of total proteins at the end of the experiment may be due to decrease in insoluble concentration and deficiency of nutrients which increase protolysis (Cooke et al., 1979 and 1980) and/or to decrease in the rate of protein synthesis (Vaodia and Waisal, 1967). Although total proteins content decreased under the stress effect of Irgarol yet protein groups differed under the stress effect of the different levels of Irgarol. Soluble proteins increased by increasing the concentration of Irgarol, while insoluble one decreased, i.e. the greater the toxic effect of the antifouling agent Irgarol and the length of culturing period, the greater the content of soluble proteins and the less of the content of insoluble fraction, This means that, the increase in the soluble proteins and the decrease in the insoluble one may be due to the degradation in insoluble fractions to soluble one or may be due to the decrease in the synthesis of insoluble one and to the accumulation of the soluble proteins under the toxic stress of this antifouling agent. It must be mentioned that, the ability of Irgarol degradation was considered to be species dependent upon expense to Irgarol. The first phase would be its rapid biosorprtion onto the cell surface. This antifouling compounds then accessed to the cell interior through diffusion or via some ion channels as proposed by St-louis et al., (1997). 
Table (2-A): Content of protein fractions $(\mathrm{mg} / \mathrm{ml})$ in Dunaliella salina cultured for 16 days under the effect of different concentrations of $\mathrm{Cu}^{2+}(5,15,25 \mathrm{mg} / \mathrm{l})$.

\begin{tabular}{|c|c|c|c|c|c|c|c|}
\hline \multirow{2}{*}{$\begin{array}{c}\text { Time } \\
\text { (Days) }\end{array}$} & \multirow[t]{2}{*}{ Parameter } & \multirow[t]{2}{*}{ Control } & \multicolumn{3}{|c|}{ Different concentrations of $\mathrm{Cu}^{2+}(\mathrm{mg} / \mathrm{l})$} & \multirow[t]{2}{*}{$\overline{F(p)}$} & \multirow[t]{2}{*}{$\overline{\text { LSD }}$} \\
\hline & & & 5 & 15 & 25 & & \\
\hline \multirow{3}{*}{$\mathbf{0}$} & Soluble & $\mathbf{5 . 2 4 9} \pm 0.002^{\mathrm{a}}$ & $\mathbf{5 . 2 4 9} \pm 0.002^{\mathrm{a}}$ & $\mathbf{5 . 2 4 9} \pm 0.002^{\mathrm{a}}$ & $\mathbf{5 . 2 4 9} \pm 0.002^{\mathrm{a}}$ & $\begin{array}{c}42024.884 * * \\
(<0.001) \\
\end{array}$ & 0.002 \\
\hline & Insoluble & $6.204 \pm 0.002^{\mathrm{a}}$ & $6.204 \pm 0.002^{\mathrm{a}}$ & $6.204 \pm 0.002^{\mathrm{a}}$ & $6.204 \pm 0.002^{\mathrm{a}}$ & $\begin{array}{c}290036.34 * * \\
(<0.001) \\
\end{array}$ & 0.002 \\
\hline & Total & 11.453 & 11.453 & 11.453 & 11.453 & & \\
\hline \multirow{3}{*}{4} & Soluble & $9.221 \pm 0.002^{a}$ & $\overline{\mathbf{9 . 7 3 4} \pm 0.001^{\mathrm{b}}}$ & $\overline{8.196} \pm 0.002^{\mathrm{c}}$ & $6.849 \pm 0.004^{e}$ & $\begin{array}{c}189355.03 * * \\
(<0.001)\end{array}$ & 0.003 \\
\hline & Insoluble & $10.226 \pm 0.002^{\mathrm{a}}$ & $10.793 \pm 0.002^{b}$ & $8.842 \pm 0.002^{c}$ & $\mathbf{7 . 8 5 0} \pm 0.001^{\mathrm{f}}$ & $\begin{array}{c}42666.09 * * \\
(<0.001)\end{array}$ & 0.002 \\
\hline & Total & 19.447 & 20.527 & 17.038 & 14.699 & & \\
\hline \multirow[t]{3}{*}{8} & Soluble & $20.625 \pm 0.004^{\mathrm{a}}$ & $22.963 \pm 0.003^{b}$ & $17.325 \pm 0.004^{d}$ & $\overline{6.9 .941 \pm 0.004^{f}}$ & $\begin{array}{c}14105523 * * \\
(<0.001)\end{array}$ & $\overline{0.003}$ \\
\hline & Insoluble & $\mathbf{2 2 . 1 6 1} \pm 0.001^{\mathrm{a}}$ & $\mathbf{2 5 . 0 4 5} \pm 0.004^{b}$ & $19.187 \pm 0.001^{d}$ & $\mathbf{7 . 4 5 8} \pm 0.001^{\mathrm{f}}$ & $\begin{array}{c}21381462^{* * *} \\
(<0.001) \\
\end{array}$ & 0.003 \\
\hline & Total & 42.786 & 48.008 & 36.512 & 14.399 & & \\
\hline \multirow{3}{*}{12} & Soluble & $23.344 \pm 0.003^{a}$ & $21.852 \pm 0.001^{b}$ & $15.582 \pm 0.002^{d}$ & $\mathbf{3 . 1 9 8} \pm 0.002^{f}$ & $\begin{array}{c}34034526 * * * \\
(<0.001)\end{array}$ & 0.003 \\
\hline & Insoluble & $26.246 \pm 0.005^{a}$ & $26.297 \pm 0.003^{b}$ & $20.788 \pm 0.005^{d}$ & $\mathbf{3 . 5 9 5} \pm 0.001^{\mathrm{f}}$ & $\begin{array}{c}47651325 * * \\
(<0.001) \\
\end{array}$ & 0.003 \\
\hline & Total & 49.608 & 48.149 & 36.370 & 6.793 & & \\
\hline \multirow{3}{*}{16} & Soluble & $26.410 \pm 0.004^{\mathrm{a}}$ & $18.061 \pm 0.001^{b}$ & $\overline{10.102} \pm 0.001^{\mathrm{d}}$ & 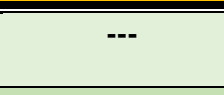 & $\begin{array}{c}1032 \times 10^{8 * * *} \\
(<0.001) \\
\end{array}$ & $\overline{0.002}$ \\
\hline & Insoluble & $\mathbf{3 0 . 3 1 9} \pm 0.007^{\mathrm{a}}$ & $24.660 \pm 0.004^{b}$ & $13.952 \pm 0.002^{d}$ & --- & $\begin{array}{c}60366139 * * \\
(<0.001)\end{array}$ & 0.004 \\
\hline & Total & 56.729 & 42.721 & 24.054 & --- & & \\
\hline
\end{tabular}

F (p): F-test (ANOVA) and its significance between groups.

* : Statistically significant at $\mathbf{p} \leq \mathbf{0 . 0 5}$.

Different subscribts are significant .
LSD: Least significant difference at 0.05 .

**: Statistically significant at $\mathrm{p} \leq \mathbf{0 . 0 1}$.

Data are expressed in mean \pm SD 
Table (2-B): Content of protein fractions $(\mathrm{mg} / \mathrm{ml})$ in Dunaliella salina cultured for 16 days under the effect of different concentrations of Irgarol $1051(0.012,0.025$ and $0.050 \mu \mathrm{g} / \mathrm{l})$.

\begin{tabular}{|c|c|c|c|c|c|c|c|}
\hline \multirow{2}{*}{$\begin{array}{c}\text { Time } \\
\text { (Days) }\end{array}$} & \multirow[t]{2}{*}{ Parameter } & \multirow[t]{2}{*}{ Control } & \multicolumn{3}{|c|}{ Irgarol 1051 concentrations $(\mu \mathrm{g} / \mathrm{l})$} & \multirow[t]{2}{*}{$\mathbf{F}(\mathbf{p})$} & \multirow[t]{2}{*}{$\overline{\mathrm{LSD}}$} \\
\hline & & & 0.012 & 0.025 & $\mathbf{0 . 0 5 0}$ & & \\
\hline \multirow{3}{*}{$\mathbf{0}$} & Soluble & $\mathbf{5 . 2 4 9} \pm 0.002^{\mathrm{a}}$ & $5.249 \pm 0.002^{\mathrm{a}}$ & $5.249 \pm 0.002^{\mathrm{a}}$ & $\mathbf{5 . 2 4 9} \pm 0.002^{\mathrm{a}}$ & $\begin{array}{c}42024.884 * * * \\
(<0.001)\end{array}$ & 0.002 \\
\hline & Insoluble & $6.204 \pm 0.002^{\mathrm{a}}$ & $6.204 \pm 0.002^{\mathrm{a}}$ & $6.204 \pm 0.002^{\mathrm{a}}$ & $6.204 \pm 0.002^{\mathrm{a}}$ & $\begin{array}{c}290036.34 * * \\
(<0.001)\end{array}$ & 0.002 \\
\hline & Total & 11.453 & 11.453 & 11.453 & 11.453 & & \\
\hline \multirow{3}{*}{4} & Soluble & 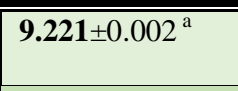 & $\overline{11.070} \pm 0.001^{\mathrm{b}}$ & $\overline{10.583} \pm 0.001^{\mathrm{c}}$ & 111.029 $\pm 0.003^{\mathrm{d}}$ & $\begin{array}{c}19895819 * * \\
(<0.001)\end{array}$ & $\overline{\overline{0.003}}$ \\
\hline & Insoluble & $10.226 \pm 0.002^{a}$ & $7.055 \pm 0.003^{b}$ & $8.274 \pm 0.003^{c}$ & $\mathbf{5 . 5 6 1} \pm 0.014^{\mathrm{d}}$ & $\begin{array}{c}29393334 * * \\
(<0.001)\end{array}$ & 0.002 \\
\hline & Total & 19.447 & 18.125 & 18.857 & 16.590 & & \\
\hline \multirow[t]{3}{*}{8} & Soluble & $2 \mathbf{2 0 . 6 2 5} \pm 0.004^{\mathrm{a}}$ & $\overline{14.081} \pm 0.004^{b}$ & $2 \mathbf{2 0 . 0 5 1} \pm 0.002^{c}$ & $16.420 \pm 0.007^{d}$ & $\begin{array}{c}31577920 * * * \\
(<0.001)\end{array}$ & 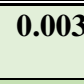 \\
\hline & Insoluble & $22.161 \pm 0.001^{a}$ & $16.201 \pm 0.001^{b}$ & $14.450 \pm 0.003^{c}$ & $\mathbf{1 0 . 0 5 0} \pm 0.004^{\mathrm{d}}$ & $\begin{array}{c}40250405 * * \\
(<0.001)\end{array}$ & 0.003 \\
\hline & Total & 42.786 & 30.282 & 34.501 & 26.470 & & \\
\hline \multirow{3}{*}{12} & Soluble & $23.344 \pm 0.003^{\text {a }}$ & $\overline{\mathbf{2 5 . 2 6 0} \pm 0.002^{\mathrm{b}}}$ & $\overline{26.030 \pm 0.005^{c}}$ & $\overline{16.551 \pm 0.021^{\mathrm{d}}}$ & $\begin{array}{c}61389579 * * * \\
(<0.001) \\
\end{array}$ & $\overline{\overline{0.002}}$ \\
\hline & Insoluble & $26.246 \pm 0.005^{a}$ & $15.222 \pm 0.004^{b}$ & $12.468 \pm 0.021^{c}$ & $7.515 \pm 0.070^{\mathrm{d}}$ & $\begin{array}{c}40303137 * * \\
(<0.001)\end{array}$ & 0.004 \\
\hline & Total & 49.608 & 40.482 & 38.498 & 24.066 & & \\
\hline \multirow{3}{*}{16} & Soluble & $26.410 \pm 0.004^{a}$ & $\overline{\mathbf{2 4 . 2 0 0} \pm 0.001^{\mathrm{b}}}$ & $\overline{20.520} \pm 0.004^{c}$ & $\overline{15.210} \pm 0.041^{\mathrm{d}}$ & $\begin{array}{c}14105523 * * * \\
(<0.001)\end{array}$ & $\overline{0.003}$ \\
\hline & Insoluble & $30.319 \pm 0.007^{\mathrm{a}}$ & $21.556 \pm 0.003^{b}$ & $16.604 \pm 0.007^{\mathrm{c}}$ & $11.233 \pm 0.052^{\mathrm{d}}$ & $\begin{array}{c}21381462 * * \\
(<0.001)\end{array}$ & 0.003 \\
\hline & Total & 56.729 & 45.756 & 37.124 & 26.443 & & \\
\hline
\end{tabular}

F (p): F-test (ANOVA) and its significance between groups. at 0.05 . * : Statistically significant at $\mathbf{p} \leq \mathbf{0 . 0 5}$. 0.01. Different subscribts are significant.
LSD: Least significant difference $* *$ : Statistically significant at $\mathbf{p} \leq$ Data are expressed in mean \pm SD 


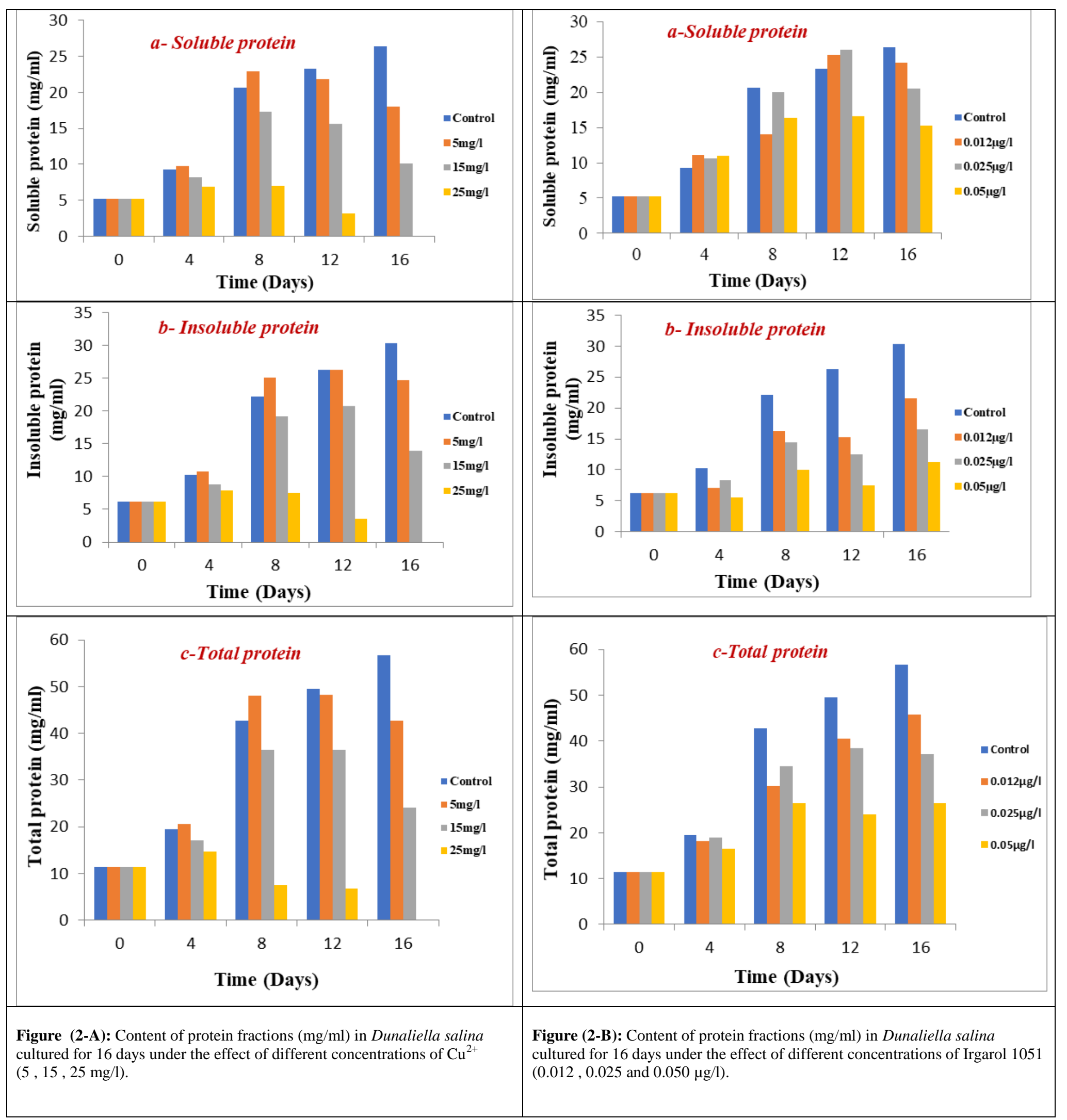




\section{3-Carbohydrates}

A glance of result recorded in Table (3-A) and graphed in Figure (3-A), concerning the effect of different concentrations of $\mathrm{Cu}^{2+}$ and Irgarol 1051 on the carbohydrate content (soluble, insoluble and total) in Dunaliella salina cultured for 16 days, it is clear that , in case of $5 \mathrm{mg} / \mathrm{l}$ of $\mathrm{Cu}^{2+}$ the total content of carbohydrates recorded the same value compared to control at the first 4 days of culturing, then the contents of total carbohydrates increased over control till the $12^{\text {th }}$ day of culturing. However, at the $16^{\text {th }}$ day of culturing the content of carbohydrates increased more than at the $12^{\text {th }}$ day of culturing, yet the value obtained was less than control. On the contrary at concentrations 15 and $25 \mathrm{mg} / \mathrm{l}$ of $\mathrm{Cu}^{2+}$, the toxic effect of $\mathrm{Cu}^{2+}$ ions increases gradually with increasing the concentration of element and period of culturing. At the $16^{\text {th }}$ day of culturing, total carbohydrate content was undetected at concentration $25 \mathrm{mg} / \mathrm{l}$ due to highly toxic effect .

As previously reported, at low concentrations of $\mathrm{Cu}^{2+}$, the stimulation of growth of Dunaliella salina was accompanied by an increase in total soluble carbohydrates. It is worth mentioning here that the movement of copper into cell is believed to occur mainly by non metabolic transport and the plasmalemma is the initial site of copper binding in the sequence leading to intracellular copper uptake thus, factor limiting the binding of copper to the plasmalemma or preventing further passage of copper into cells will similarly limit copper toxicity (Vymazal, 1995). In other studies, Twiss and Nalewajko, (1992) suggested that polyphosphate plays a passive role in protecting cells from copper.

Our results go with harmony with those obtained by Chi et al., (2006), they found that heavy metals released from AF coatings tend to cause change in the growth and biochemical metabolism of the marine organisms.

Results obtained from the experiments recorded in Table (3-B) and graphed in Figure (3B) that have been carried out on the effect of Irgarol on the carbohydrates content revealed that, all the tested concentrations of Irgarol were inhibitor to carbohydrates content of Dunaliella salina. These results go in harmony with those obtained by Sidharthanet al., (2002) who reported that, high concentration of TBT on $1.0 \mathrm{ng} / \mathrm{l}$, the proteins and carbohydrates were inhibited in Nannochloropsis oculata and bring about drastic change in its biochemical compositions.

Khodse and Meana,(2007) found that, antifouling agents like TBT and Irgarol influenced cellular and extracellular carbohydrate production. The results obtained in this investigation are in harmony with those recorded for such authors. Also, Mishra et al., (2008) reported that, among different solute accumulating in response of stress, sugar play a key role to maintain the osmotic regulation in cells. 
Table (3-A): Content of carbohydrate fractions (soluble, insoluble and total in $\mathrm{mg} / \mathrm{l}$ ) in Dunaliella salina under the effect of different concentrations of $\mathrm{Cu}^{2+}(5,15$ and $25 \mathrm{mg} / \mathrm{l})$.

\begin{tabular}{|c|c|c|c|c|c|c|c|}
\hline \multirow{2}{*}{$\begin{array}{l}\text { Time } \\
\text { (Days) }\end{array}$} & \multirow[t]{2}{*}{ Parameter } & \multirow[t]{2}{*}{ Control } & \multicolumn{3}{|c|}{$\begin{array}{c}\text { Different concentrations of } \mathrm{Cu}^{2+} \\
(\mathrm{mg} / \mathrm{l})\end{array}$} & \multirow[t]{2}{*}{$\mathbf{F}(\mathbf{p})$} & \multirow[t]{2}{*}{ LSD } \\
\hline & & & 5 & 15 & 25 & & \\
\hline \multirow[t]{3}{*}{$\mathbf{0}$} & Soluble & $\mathbf{5 . 5 9} \pm 0.002^{a}$ & $\mathbf{5 . 5 9} \pm 0.002^{\mathrm{a}}$ & $\mathbf{5 . 5 9} \pm 0.002^{\mathrm{a}}$ & $\mathbf{5 . 5 9} \pm 0.002^{\mathrm{a}}$ & $\begin{array}{c}386923.80 * * \\
(<0.001)\end{array}$ & 0.002 \\
\hline & Insoluble & $\mathbf{1 3 . 6 7} \pm 0.001$ & $\mathbf{1 3 . 6 7} \pm 0.001^{\mathrm{a}}$ & $\mathbf{1 3 . 6 7} \pm 0.001^{\mathrm{a}}$ & $13.67 \pm 0.001^{\mathrm{a}}$ & $\begin{array}{c}11450350 * * * \\
(<0.001)\end{array}$ & 0.002 \\
\hline & Total & 19.26 & 19.26 & 19.26 & 19.26 & & \\
\hline \multirow[t]{3}{*}{4} & Soluble & $9.69 \pm 0.002^{\mathrm{a}}$ & $9.69 \pm 0.001^{\mathrm{a}}$ & $7.23 \pm 0.004^{c}$ & $\overline{\mathbf{5 . 5 7}} \pm 0.003^{\mathrm{e}}$ & $\begin{array}{c}434608.82{ }^{* *} \\
(<0.001) \\
\end{array}$ & 0.003 \\
\hline & Insoluble & $\mathbf{a}$ & $19.15 \pm 0.002^{b}$ & $15.70 \pm 0.002^{\mathrm{d}}$ & $\mathbf{1 0 . 3 9} \pm 0.002^{f}$ & $\begin{array}{c}\mathbf{7 2 1 0 6 8 8 . 6}^{* *} \\
(<0.001)\end{array}$ & 0.002 \\
\hline & Total & 28.84 & 28.84 & 22.93 & 15.96 & & \\
\hline \multirow[t]{3}{*}{8} & 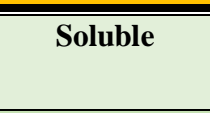 & 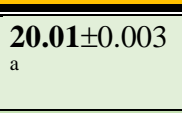 & $27.14 \pm 0.003^{b}$ & $\overline{16.99 \pm 0.002^{d}}$ & $\overline{\overline{6.73} \pm 0.001^{f}}$ & $\begin{array}{c}206431.13 \\
(<0.001) \\
\end{array}$ & 0.023 \\
\hline & Insoluble & $\mathbf{3 6 . 6 0} \pm 0.002$ & $49.62 \pm 0.002^{b}$ & $22.19 \pm 0.003^{d}$ & $12.32 \pm 0.003^{f}$ & $\begin{array}{c}1.48 \times 10^{8 * *} \\
(<0.001)\end{array}$ & 0.002 \\
\hline & Total & 56.61 & 76.76 & 39.18 & 19.05 & & \\
\hline \multirow[t]{3}{*}{12} & Soluble & $\overline{\mathrm{a}} \mathbf{2 7 . 4 3} \pm 0.001$ & $27.55 \pm 0.003^{b}$ & $\overline{13.69} \pm 0.002^{\mathrm{d}}$ & 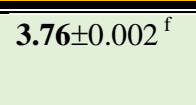 & $\begin{array}{c}\text { 48892236*** }^{*} \\
(<0.001)\end{array}$ & 0.003 \\
\hline & Insoluble & 38.30 \pm 0.004 & $\mathbf{3 9 . 2 5} \pm 0.002^{\mathrm{b}}$ & $25.45 \pm 0.004^{d}$ & $\mathbf{5 . 2 5} \pm 0.003^{f}$ & $\begin{array}{c}1.16 \times 10^{8 * *} \\
(<0.001)\end{array}$ & 0.004 \\
\hline & Total & 65.73 & 66.80 & 39.14 & 9.01 & & \\
\hline \multirow[t]{3}{*}{16} & $\overline{~ S o l u b l e ~}$ & $\overline{\mathrm{a}} \mathbf{2 4 . 1 9} \pm 0.002$ & $22.82 \pm 0.003^{b}$ & $14.14 \pm 0.003^{\mathrm{d}}$ & $\overline{\mathbf{0 0 0} \pm 0.000^{f}}$ & $\begin{array}{c}99105492^{* *} \\
(<0.001) \\
\end{array}$ & 0.002 \\
\hline & Insoluble & $\mathbf{4 3 . 4 6} \pm 0.003$ & $\mathbf{4 0 . 8 9} \pm 0.002^{\mathrm{b}}$ & $17.71 \pm 0.004^{\mathrm{d}}$ & $\mathbf{0 0 0} \pm 0.000^{\mathrm{f}}$ & $\begin{array}{c}2.05 \times 10^{8 * *} \\
(<0.001)\end{array}$ & 0.003 \\
\hline & Total & 67.56 & 63.71 & 31.85 & 000 & & \\
\hline
\end{tabular}

F (p): F-test (ANOVA) and its significance between groups.

0.05. * : Statistically significant at $\mathbf{p} \leq \mathbf{0 . 0 5}$.

0.01. Different subscribts are significant .
LSD: Least significant difference at $* *$ : Statistically significant at $\mathbf{p} \leq$ Data are expressed in mean $\pm \mathrm{SD}$ 
Table (3-B): Content of carbohydrate fractions (soluble, insoluble and total in $\mathrm{mg} / \mathrm{l}$ ) in Dunaliella salina under the effect of different concentrations of Irgarol $1051(0.012,0.025$ and $0.050 \mu \mathrm{g} / \mathrm{l})$.

\begin{tabular}{|c|c|c|c|c|c|c|c|}
\hline \multirow{2}{*}{$\begin{array}{c}\text { Time } \\
\text { (Days) }\end{array}$} & \multirow{2}{*}{ Parameter } & \multirow{2}{*}{ Control } & \multicolumn{3}{|c|}{ Irgarol 1051 concentration $(\mu \mathrm{g} / \mathrm{l})$} & \multirow[t]{2}{*}{$\overline{F(p)}$} & \multirow[t]{2}{*}{$\overline{\text { LSD }}$} \\
\hline & & & 0.012 & 0.025 & 0.050 & & \\
\hline \multirow{3}{*}{$\mathbf{0}$} & Soluble & $\mathbf{5 . 5 9} \pm 0.002^{\mathrm{a}}$ & $\mathbf{5 . 5 9} \pm 0.002^{\mathrm{a}}$ & $\mathbf{5 . 5 9} \pm 0.002^{\mathrm{a}}$ & $\mathbf{5 . 5 9} \pm 0.002^{\mathrm{a}}$ & $\begin{array}{c}386923.80 * * * \\
(<0.001)\end{array}$ & 0.002 \\
\hline & Insoluble & $13.67 \pm 0.001^{a}$ & $13.67 \pm 0.001^{a}$ & $13.67 \pm 0.001^{\mathrm{a}}$ & $13.67 \pm 0.001^{a}$ & $\begin{array}{c}11450350 * * \\
(<0.001)\end{array}$ & 0.002 \\
\hline & Total & 19.26 & 19.26 & 19.26 & 19.26 & & \\
\hline \multirow{3}{*}{4} & Soluble & $\overline{\mathbf{9 . 6 9} \pm 0.002^{\mathrm{a}}}$ & $\overline{10.84 \pm 0.4^{b}}$ & $\overline{10.35 \pm 0.08^{c}}$ & $\overline{\mathbf{8 . 0 3} \pm 0.36^{\mathrm{d}}}$ & $\begin{array}{c}12766177^{* * *} \\
(<0.001)\end{array}$ & $\overline{0.003}$ \\
\hline & Insoluble & $19.15 \pm 0.001^{\mathrm{a}}$ & $16.32 \pm 0.62^{b}$ & $12.81 \pm 0.023^{\mathrm{c}}$ & $12.28 \pm 0.002^{\mathrm{d}}$ & $\begin{array}{c}44880350 * * \\
(<0.001)\end{array}$ & 0.004 \\
\hline & Total & 28.84 & 27.20 & 23.16 & 20.31 & & \\
\hline \multirow{3}{*}{8} & Soluble & $20.01 \pm 0.003^{\mathrm{a}}$ & $\overline{20.16 \pm 0.08^{b}}$ & $\overline{\overline{12.85} \pm 0.01^{\mathrm{c}}}$ & $\overline{10.71 \pm 0.024^{\mathrm{d}}}$ & $\begin{array}{c}8582430 * * \\
(<0.001)\end{array}$ & $\overline{0.002}$ \\
\hline & Insoluble & $36.60 \pm 0.002^{a}$ & $\mathbf{1 9 . 5 4} \pm 0.05^{b}$ & $18.92 \pm 0.005^{c}$ & $13.26 \pm 0.003^{d}$ & $\begin{array}{c}65470628 * * \\
(<0.001) \\
\end{array}$ & 0.004 \\
\hline & Total & 56.61 & 39.70 & 31.77 & 23.97 & & \\
\hline \multirow{3}{*}{12} & Soluble & 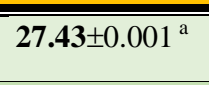 & 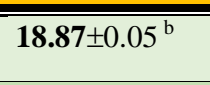 & $\overline{15.38 \pm 0.004^{c}}$ & 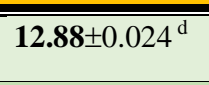 & $\begin{array}{c}69301031 * * \\
(<0.001) \\
\end{array}$ & $\overline{\overline{0.002}}$ \\
\hline & Insoluble & 38.30 $\pm 0.004^{\mathrm{a}}$ & $26.64 \pm 0.08^{b}$ & $\mathbf{2 3 . 3 4} \pm 0.002^{\mathrm{c}}$ & $\mathbf{1 5 . 3 4} \pm 0.003^{\mathrm{d}}$ & $\begin{array}{c}93391209 * * \\
(<0.001)\end{array}$ & 0.004 \\
\hline & Total & 65.73 & 45.42 & 38.72 & 28.22 & & \\
\hline \multirow{3}{*}{16} & Soluble & 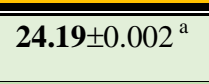 & $\overline{19.85 \pm 0.09^{b}}$ & $\overline{19.90 \pm 0.002^{c}}$ & $\overline{16.55 \pm 0.11^{\mathrm{d}}}$ & $\begin{array}{c}206431.13 * * * \\
(<0.001)\end{array}$ & $\overline{0.023}$ \\
\hline & Insoluble & $43.46 \pm 0.003^{\mathrm{a}}$ & $29.01 \pm 0.14^{b}$ & $17.66 \pm 0.003^{c}$ & $\mathbf{1 0 . 0 8} \pm 0.013^{\mathrm{d}}$ & $\begin{array}{c}1.48 \times 10^{8 * * *} \\
(<0.001)\end{array}$ & 0.002 \\
\hline & Total & 67.56 & 48.86 & 37.56 & 26.63 & & \\
\hline
\end{tabular}

F (p): F-test (ANOVA) and its significance between groups.

* : Statistically significant at $\mathbf{p} \leq \mathbf{0 . 0 5}$.

Different subscribts are significant .
LSD: Least significant difference at 0.05 . $* *$ : Statistically significant at $\mathbf{p} \leq \mathbf{0 . 0 1}$.

Data are expressed in mean $\pm \mathrm{SD}$

There are earlier reports on carbohydrates accumulation on response of various abiotic stress during reproductive development (Meier and Reid, 1982). It was found also by Parado et al. (2000) that, accumulation of sugars is enhanced in response of verity of environmental stress. However, our work cleared that, the content of carbohydrates whether soluble, insoluble and total depended mainly on the concentration of the stress compound and the length of culturing period. This fact could be reported from the data obtained in this paper where all the carbohydrate fractions after the $16^{\text {th }}$ day of culturing greatly decreased specially at the highest concentration $(0.050 \mu \mathrm{g} / \mathrm{l})$ and the rate of decrease depended mainly on the concentration of Irgarol. The decrease in carbohydrates content may indicate that, the efficiency of photosynthesis began to decrease owing to the destruction of chloroplast pigments (Gale et al.,1966). 


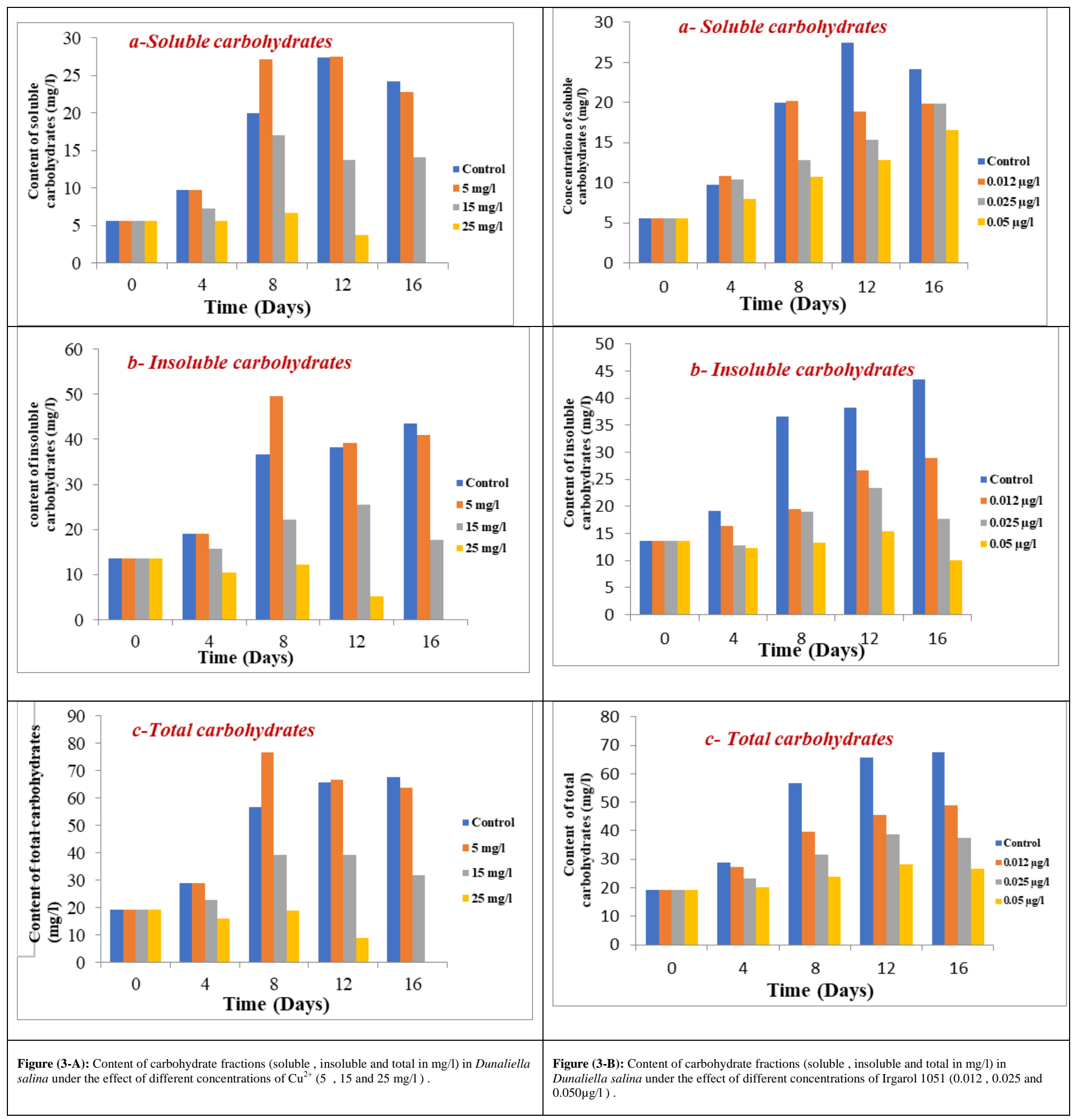




\section{CONCLUSION}

Present study aims to compare toxicity effect of Copper and Irgarol 1051 as two antifouling agents on metabolites products in marine algae Dunaliella salina. Different concentrations of $\mathrm{Cu}(5,15 \& 25 \mathrm{mg} / \mathrm{l})$ and Irgarol $1051(0.012,0.025 \& 0.050 \mu \mathrm{g} / \mathrm{l})$ were laboratory prepared and their impacts on growth, protein and carbohydrates on Dunaliella salina. The obtained data were analyzed statistically using two ways ANOVA. The difference between means probability levels were analyzed using Duncan's New Multiple Range. Results showed that at low concentration of $\mathrm{Cu}^{2+}$ ions (i.e. $5 \mathrm{mg} / \mathrm{l}$ ), the growth of algae stimulated compared to control. However, the cell is gradually decreased at high concentration of $\mathrm{Cu}^{2+}$ ions $(15,25 \mathrm{mg} / \mathrm{l})$. In regard of Irgarol 1051, a gradual increase in number of cells was recorded till the end of the experiment with concentration $0.012 \mu \mathrm{g} / \mathrm{l}$, however percontra at concentrations 0.025 and $0.050 \mu \mathrm{g} / 1$ was great decrease in number of cells after $6^{\text {th }}$ day till the end of the experiment compared to concentration $0.012 \mu \mathrm{g} / \mathrm{l}$. There was suppression of algal growth under the effect of the different tested concentrations of Irgarol which may be due to increase toxicity of this biocide. At concentration $25 \mathrm{mg} / \mathrm{l}$ of $\mathrm{Cu}^{2+}$, there was a steep decrease in protein content (soluble, insoluble and total) higher than in case of concentration $15 \mathrm{mg} / \mathrm{l} \mathrm{of} \mathrm{Cu}^{2+}$ and after the $12^{\text {th }}$ day no protein detected indicating to a toxic effect. The greater the toxic effect of the antifouling agent Irgarol and the length of culturing period, the greater the content of soluble proteins and the less content of insoluble fraction. The decrease in the content of total proteins at the end of the experiment may be due to decrease in insoluble concentration and deficiency of nutrients which induces protolysis. The toxic effect of $\mathrm{Cu}^{2+}$ ions increase gradually with increasing the concentration of element and period of culturing, however concentrations of Irgarol even very low were inhibitor to carbohydrates content of Dunaliella salina. Vulnerability of Dunaliella salina to Irgarol 1051 and $\mathrm{Cu}$ showed different responses. The damage resulted from existence of Dunaliella algae in marine environment with very low concentrations of Irgarol 1051 is much more than $\mathrm{Cu}$. This can be explained by the high toxicity level of Irgarol, which is classified as a toxic antifouling in comparison with $\mathrm{Cu}$ which is one of the essential micronutrients in marine ecosystem.

\section{REFERENCES}

Abalad, J., Cid; Herrero, A. C. and Torres, E. (1995b). Response of the marine micro-alga Dunaliella tertiolecta to copper toxicity in short time experiments. Bull. Environ. Contam. Toxicology, 54, 317.

Abd El-Baky, H.H.; Moawd, A.; El-Behairy, A.N. and El-Baroty, G.S. (2002). Chemoprevention of benzo[a]pyrene-induced carcinogen and lipid peroxidation in mice by lipophilic algae extracts (phycotene). J. Med. Sci. 2: 185-93.

Abdel-Hamid, M.I.; Shaaban-Dessouki, S.A. and Skulberg, O.M. (1992). Water quality of the river Nile in Egypt. II. Water fertility and toxicity evaluated by an algal growth potential test. Arch. Hydrobiol. Suppl., 90(3), 311. 
Amara, I.; Miled, W.;Slama, R.B. and Ladhari, N.( 2018). Antifouling processes and toxicity effects of antifouling paints on marine environment. A review. Environmental Toxicology and Pharmacology 57: 115-130.

Anita, G.J. Buma; Sascha, B. Sjollema; Willem, H. van de Poll; Han,S. J.C. Klamer and Joop, F. Bakker.(2009).Impact of the antifouling agent Irgarol 1051 on marine phytoplankton species. Journal of Sea Research 61:133-139.

Assessment of Antifouling Agents in Coastal Environments (ACE) MAS3-CT98-0178, (2002). Final Scientific and Technical Report European Commission, pp. 1-53.

Bascher, C.;Tan KS. and Lee, HK. (2002). Organotin and Irgarol-1051 contamination in Singapore coastal waters. Mar. Poll. Bull. 44:697-703.

Ben-Amotz, A. and Avron, M. (1981). Glecerol and B-carotene metabolism in the halotolerant alga Dunaliella, a model system for biosolar energy conversion. Trends of Biochemistry Science, 6,297-299.

Biselli, S.; Bester, K.; Huhnerfuss, H. and Fent, K. (2000). Concentrations of the antifouling compound Irgarol 1051 and of organotins in water and sediments of German North and Baltic Sea marinas. Mar. Poll. Bull. 40:233-243

Brooks, S. and Waldock, M. (2009). The use of copper as a biocide in marine antifouling paints. In: Hellio, C., Yebra, D. (Eds.), Advances in Marine Antifouling Coatings and Technologies. Woodhead Publishing Limited, Cambridge, pp. 492-521.

Chi, Young Lim; Yong Hoon Yoo, M.; Sidharthan, Chae Woo Ma; In Chul Bang; Jong Man Kim; Kwang Soo Lee; Nam Sik Park and H.W. Shin. (2006). Effects of copper (I) oxide on growth and biochemical compositions of two marine microalgae. Journal of Environmental Biology. 27(3) 461-466.

Cid, A.; Fidalgo, P.; Herrero, C. and abalde, J. (1996). Toxic action of $\mathrm{Cu}$ on the membrane Bystem of a marine diatom measured by flow cytometry. Cytometry, 25: 32-36.

Cooke, R.J.; Oliver, J. and Davis, D.D. (1979). Stress and protein turnover in Lemna minor. Plant Physiol. 64: 1109-1113.

Cooke, R.J.; Roberts, K. and Davis, D.D. (1980). Model for stress induced protein degradation in Lemna minor. Plant Physiol. 66: 1119-1122.

Dahl, B. and Blanck, H.(1996). Toxic effects of the antifouling agent Irgarol 1051 on periphyton communities in coastal water microcosms. Mar. Poll. Bul. 32 (4), 342-350.

Davey, E.W.; Morgan, M.J. and Erickson, S.J. (1973). A biological measurement of copper complexation capacity of seawater. Limnol. Oceanogr., 12, 319-323.

Dubois, M.; Gilles, K.A.; Hamilton, J.K. and Smith, F. (1959). Phenol-sulphoric acid colorimetric method for carbohydrate determination. In: Methods in carbohydrate chemistry. Whist ler, L.R. and Wolform, R.L. (ed.) 388-403. Academic press New York.

E. Almeida; T.C. Diamantino and O. de Sousa. (2007). Marine paints: the particular case ofantifouling paints, Prog. Org. Coat. 59 :2-20. 
El-Maghrabi D.M. (1997). The biotechnology of culturing Dunaliella salina for the production of some valuable metabolites. M.Sc. Thesis. Fac. of Sci. Alex. Univ. Egypt.

Erik Ytreberg ; Maria Lagerström ; Sofia Nöu ; Ann-Kristin E. Wiklund. (2021).Environmental risk assessment of using antifouling paints on pleasure crafts in European Union waters. Journal of Environmental Management 281:111846.

Farouk K. El-Baz; Sayeda M. Abdo and Ahmed M.S. Hussein.(2017). Microalgae Dunaliella salina for use as Food Supplement to Improve Pasta Quality. Int. J. Pharm. Sci. Rev. Res., 46(2): 45-51.

Gale, J; Kohl, H. C. and Hagan, R.M. (1966). Mesophyll and stomatal resistance affecting photosynthesis under varying conditions of soil water and evaporation demand . Israel. J. Bot. 15:64-71.

Gatidou, G; Kotrikla, A; Rontogianni, V; Thomaidis, N.S and Lekkas, T.D. ( 2003). The toxic effects of the antifouling biocide Irgarol 1051 and its principal metabolite on the green alga Dunaliella tertiotecta. 8th International Conference on Environmental Science ad Technology, Lemnos island, Greece.

Gatidou,G; Kotrikla, A; Rontogianni, V and Thomaidis, N.S. (2003). Toxic effect of the antifouling biocide Irgarol 1051 and its principal metabolites on the green alga Dunaliella tertiolecta. $8^{\text {th }}$ international conference on environmental science and technology.

Hall Jr.L.W; Gidding, J.M; Solomon, K.R. and Balcomb, R. (1999). An ecological risk assessment for the use of Irgarol 1051 as an algaecide for antifoulingpaints. Crit. Rev. Toxicol.29 (4),367-437.

Han, T; Kang, S.-H., Park, J.-S; Lee, H.-K and Brown, M.T. (2008). Physiological responses of Ulva pertusa and U. armoricana to copper exposure. Aquat. Toxicol. 86: 176- 184.

Hartree, E.F. (1972). A modification of Lowry method that gives a linear photometric response. Analyt. Biochem. 48: 422.

Hosseini, T. A. and Shariati, M. (2009). Dunaliella biotechnology: methods and applications. J. of applied microbiology.:107 (1): 14-35.

Indira and Biswajit.(2012) Commercial and industrial applications of micro algae - A review. $J$. Algal Biomass Utln. 3 (4): 89-100.

Ivaylo, S.; Katya, V.; Stefka, S. and Yordan, S.(2015). The importance of microalgae for aquaculture industry. Review. International Journal of Fisheries and Aquatic Studies. 2(4): 81-84.

Jaime Fabregas and Concepcion Herrero .(1985). Marine microalgae as a potential source of single cell protein. Appl Microbiol Biotechnol (1985) 23:110—113.

Key, PB.; Chung, KW.; Hoguet, J.; Sapozhnikova, Y. and Fulton, MH. (2008). Effects of the anti-fouling herbicide Irgarol 1051 on two life stages of the grass shrimp, Palaemonetes pugio. J. Environ. Sci. Health B. 43(1):50 - 55.

Konstantinou, I.K. and Albanis, T.A. (2004). Worldwide occurrence and effects of antifouling paint booster biocides in the aquatic environment: A review. Environ. Intern. 30: 235-248. 
Lage, O.M.; A.M. Parente, M.T.S.D. Vasconcelos and Gomes, C.A.R.. (1996). Potential tolerance mechanisms of Prorocentrum micans (Dinophyceae) to sublethal levels of copper. J. Phycol., 32: 416-423.

Lewis, A.G. and Cave, W.R., (1982). The biological importance of copper in oceans and estuaries. Oceanogr. Mar. Biol. Annu. Rev. 20: 471-695.

Lindgren, J.F.; Ytreberg, E.; Holmqvist, A.; Dahlström, M.; Dahl, P.; Berglin, M.; Wrange, A.-L. and Dahlström, M.( 2018). Copper release rate needed to inhibit fouling on the west coast of Sweden and control of copper release using zinc oxide. Biofouling 34: 453-463.

Loeblich, L.A. (1982). Photosynthesis and pigments influenced by light intensity and salinity in the halophilic Dunaliella salina (Chlorophyta). J. Mar. Biol. Ass. UK., 62: 493-508.

Lowery, O.M.; Rosebrough, N.J.; Farr, L.A. and Randall, R.J. (1951). Protein measurements with folin phenol reagent. J. Biol. Chem. 193: 265-275.

Meier, H. and Reid, J.S.G. (1982). Reverse polysaccharides other than starch in higher plants. In: Loewus F.A. and Tanner, W. (eds), Encyclopedia of Plant Physiology. New series. SpringerVerlag, Berlin, pp.418-471.

Mishra, A.; Mandoli, A. and Jha, B. (2008). Physiological characterization and stress-induced metabolic responses of Dunaliella salina isolated from salt pan. J. Ind. Microbiol. Biotechnol. 35: 1093-1101.

Munnas, R. (2003). Comparative physiology of salt and water stress. Plant Cell Environ. 25: 239-250.

El-Agwany, N.I. (2008).Metabolic response of Dunaliella tertiolecta to toxicity of some metals in relation to phosphorus availability. Ph.D.

Ochoa-Herrera, V.; Leon, G.; Banihani, Q.; Field, J.A. and Sierra-Alvarez, R. (2011). Toxicity of copper(II) ions to microorganisms in biological wastewater treatment systems. Sci. Total Environ. 412-413: 380-385.

Prado, F.E., Boero, C.; Gallardo, M. and Gonzalez, J.A. (2000). Effect of $\mathrm{NaCl}$ on germination, growth and soluble sugar content in Chenopodium quinoa wild seeds. Bot. Bull. Acad. Sin. 41:27-34.

Rauch, T. (1981). The estimation of microalgal protein content and its meaning to the evolution of algal biomass. I., Comparison method for extracting protein. Hydrobiologia. 78: 237.

Readman, J.W.; Devilla, R.A..; Llewellyn, C.A.; Fileman, W.; Easton A.; Buckhill, P.H. And Mantoura, R.F.C. (2004). Flow cytometry and pigment analyses as tools to investigate the toxicity of herbicides to natural phytoplankton communities. Mar. Environ. Res. 58:353.

Readman, J.W.; Liong, L.L W.; Grondin, D.; Bartocci, J.; Villeneuve, J.P.and Mee, L.D. (1993). Coastal water contamination of a triazine herbicide used in antifouling paints. Environ.Sci. Technol. 27(9): 1940-1942.

Rhie, K.T. and Lee, K.S. (1999). The algal phosphorus uptake and growth by copper and methylglyoxal. Kor. J. Environ. Toxicol., 14: 145-153. 
Sahar, M.M.I. (1998). Biotechnological studies on Dunaliella $\beta$-carotene production properties and utilization as food additive. M.sc. Thesis. Fac. of Agriculture. Alex. Univ. Alex. Egypt.

Sidharthan, M.; Kim Shin, Y.; Lee Hoe, W., Park Kwan, S. and Hyun Wung, S. (2002). TBT toxicity on the marine microalga Nannochloropsis oculata. Mar. Pollut. Bull. 45:177-180.

Singla, R. and Garg, N. (2005). Influence of salinity on growth and yield Attributes in Chickpea Cultivars. Turk. J.Agric. For.29: 231-235.

Spindler, P. H. (1993). Algal distribution and chemical gradients in Pinal Creek, Gila Country". Az. M.s. Thesis, Arizona State University, Tempe, Az, 73 pp.

Srinivasan, M, and Swain, G. (2007). Managing the use of copper-based antifouling paints. Environ. Manage. 39: 423-441.

Stauber, J.L. and Florence, T.M. (1985a). Interaction of copper and manganese: a mechanism by which manganese alleviate copper toxicity to the marine diatoms (Her.) W. Smith. Aquatic Toxicol., 7: 241.

Steeman-Nielsen, E. and Wium-Anderson, S. (1970). Copper ions as poison in the sea and in freshwater. Mar. Bio., 6: 93.

Stein, J.R. (1973). Hand book of phycological methods. Culture method and growth measurements. Cambridge University press, London.

Stewart, P.M.(1995). Use of algae in aquatic pollution assessment .Nat. Areas J. 15(3): 234-239.

St-Louis, R.; Pelletier, E. and Marsot, P. (1997). A mechanism approach to tributyltin (TBT) sorption by marine micro flagellated alga Pavlova lutheri. Applied Organometallic Chemistry. 11: 543-550.

Strivens, J.; Hayman, N.; Rosen, G. and Myers-Pigg, A. (2020). Toward validation of toxicological interpretation of diffusive gradients in thin films in marine waters impacted by copper. Environ. Toxicol. Chem. 39: 873-881.

Thompson, P.A.; Couture, P.; Thellen, C. and. Auclair, J.C. (1987). Structurefunction relationships for monitoring cellular stress and recovery responses with Selenastrum capricornutum. Aquatic Toxicol., 10: 291-305.

Tsang, C.K.; Lau, P.S.; Tam, N.F.Y. and Wong, Y.S. (1999). Biodegradation capacity of tributyltin by two Chlorella species. Environmental Pollution. 105: 289-297.

Twiss, M.R. and Nalewajko, C. (1992). Influence of phosphorus nutrition on copper toxicity to three strains of Scenedesmus acutus (Chlorophyceae). J. Phycol. 28: 291-298.

Valkirs, A.O.; Seligman P.E.; Haslbeck E. and J.S. Caso. (2003). Measurement of copper release rates from antifouling paint under laboratory and in situ conditions: implications for loading estimation to marine water bodies. Mar. Pollut. Bull., 46, 763-779.

Van Wezel, A.P. and Van Vlaardingen, P. (2004). Environmental Risk Limits for Antifouling Substances. Aquat. Toxicol. 66: 427- 444.

Vaodia, Y. and Waisal, Y.(1967). Physiological processes as affected by water balance. In: "Irrigation of Agricultural lands" (R.M.Hagen, H.R.Haise, T.W.Edminster, eds). 
Vymazal, J. (1995). Algae and element cycling in wetlands. Lewis publishers Boca Raton, Ann Arbor, London\& Tokyo, 64pp.

Wong, M.H. and Pak, D.C.H. (1992). removal of copper and nickel by free and immobilized microalgae. Biomedical and Environmental Sciences, 5: 99-108.

Wong, P.K. and Chang, L. (1991). Effect of copper, chromium and nickel on growth, photosynthesis and chlorophyll-a synthesis of Chlorella pyrenoidosa. Environ. Pollut., 72: 127139.

Xie, Z.C.; Wong, N.C.; Qian, P.Y. and Qiu, J.W. (2005). Responses of polychaete Hydroides elegans life stages to copper stress. Mar. Ecol. Prog. Ser. 285: 89-96.

Yebra, O.M.; Kiil, S. and Dam-Johansen, K. (2004). Prog Org Coat 50:75.

Zamora-Ley, I. M.; Gardinali, P.R. and Jochem, F.J. (2006). Assessing the effect of Irgarol 1051 on marine phytoplankton populations in Key Largo Harbor, Florida. Marine Pollution Bulletin. 52: 935-941. 